Article

\title{
Andean Lupin Phenology and Agronomic Performance under Different Planting Dates in a Mediterranean Climate
}

\author{
Efstathia Lazaridi, George K. Papadopoulos and Penelope J. Bebeli * \\ Laboratory of Plant Breeding and Biometry, Department of Crop Science, Agricultural University of Athens, \\ 11855 Athens, Greece; e.lazaridi@aua.gr (E.L.); gpapadop@aua.gr (G.K.P.) \\ * Correspondence: bebeli@aua.gr; Tel.: +30-210-529-4626
}

Received: 22 October 2020; Accepted: 17 December 2020; Published: 21 December 2020

check for updates

\begin{abstract}
Andean lupin in Europe has regained interest in recent years due to its high seed protein and oil content and its potential use for food, feed as well as a crop used in biorefineries. A search for suitable germplasm in combination with a determination of appropriate agronomical practices such as planting date are needed for commercial farming in new areas. The current study aims to evaluate the performance of six selected L. mutabilis accessions in a Mediterranean area using two different planting dates for two consecutive experimental years. A split plot design with accessions as subplots and planting dates as main plots was used. Measurements such as days to flowering, plant height, total number of pods and seeds per plant, seed yield and seed crude protein content were taken. All accessions performed better when cultivation started not later than the end of autumn since high temperatures occurred during late spring shortened the growth cycle and reduced yield. Earlier cultivation applied, in the middle of autumn, did not enhance significantly seed yield production. Among the accessions, LIB223 was characterized by the highest seed crude protein content in the early planting treatment, while accessions with prolonged growth cycle (LIB209, LIB214 and LIB223) produced higher seed yield than other accessions and could be further studied as promising breeding material for cultivation under the edaphoclimatic conditions tested.
\end{abstract}

Keywords: Lupinus mutabilis; crude protein; lupins; nutrient content; planting date; seed production; Southern Europe; tarwi

\section{Introduction}

Lupins (Lupinus spp.) have been cultivated since antiquity [1], as a multipurpose crop used for animal feed, pasture improvement, manure and for human consumption, in food processing, medicine, cosmetics, as ornamentals, as well as for enhancing symbiotic nitrogen fixation [2-5]. They also contribute to soil erosion prevention and soil stabilisation [6], leading to soil sustainability [7].

A lupin domestication process took place in Europe, around Mediterranean Sea and in parallel, independently, in the Andes [8]. Among approximately 280 species belonging to the genus Lupinus [9], Andean lupin (Lupinus mutabilis Sweet) is the only New World cultivated species that is an agronomic crop and according to historical evidence it was well known even during the Incan empire [10,11].

Andean lupin, also known as "Tarwi" or "Chocho", was primarily domesticated around 700-600 B.C. [12]. Recently its cultivation in its center of origin has been reduced and farmers are producing it mainly for their own consumption and not for selling [13]. However, interest in Andean lupin cultivation in Europe and Australia [8] has increased in the last few decades because of its high seed protein $(>40 \%)$ [14] and its good oil quality reaching up to $20 \%[6,15,16]$, two traits that present weak or no correlation and therefore selection can be applied for high values in both [16-18]. 
Even though lupin use was restricted in the past to few areas, due to the high seed alkaloid content which can reach up to $5 \%$, the interest in this crop has been rekindled in the last few years as breeding lines with low alkaloid levels have been developed [19]. Andean lupin has been introduced into cultivation in Europe at an experimental, although not yet a commercial, scale [7]. This could be attributed to its economically insufficient yield [13] as its cultivation often results in low or unstable seed production [7] and its productivity is not comparable to that of the European domesticated lupin species, such as Lupinus albus L. and Lupinus angustifolius L. [8].

Low yield production partially is attributed to the contrasting planting dates applied and climatic conditions prevailing during initial vegetative period in the mid- to high-elevation Andean areas, like in Peru or Bolivia [20] and the different parts of Europe [16] where lupin is cultivated. More specifically, in the Andes direct sowing takes place in a warm and rainy season favorable for Andean lupin [16] while a spring direct sowing and short cultivation period that lasts till autumn is usually applied in Northern European countries. On the other hand, an autumn direct sowing takes place in Southern Europe followed by a cold, rainy winter as well as terminal drought stress and high air temperature early in the summer that often leads to increased percentages of flower abortion and non-uniform pod filling $[14,21,22]$. The necessity of evaluation of L. mutabilis and other lupin species for several traits has been emphasized by Sawicka-Sienkiewicz et al. [23] and Clements et al. [24], as they can be affected significantly by environmental factors. Evaluation of germplasm in combination with determination of appropriate agronomical practices such as cultivation period across Europe is, therefore, crucial. In this respect, Galek et al. [25], assessed 12 L. mutabilis genotypes regarding their seed coat thickness for increased seed coat permeability to water, aiming to enhance seed germinability under European climatic conditions. A total number of eleven L. mutabilis indeterminate genotypes were evaluated in five locations across Europe regarding their plant architecture and phenology [26].

Due to the short cultivation period available in Northern and Central Europe, breeding for early maturity had been suggested since the late 1970s [27] and started in the early 1980s [18]. Semi-determinate and determinate growth types were developed for that reason [28-30] and many of them were derived after induced mutations [25]. In Poland, determinate and indeterminate morphotypes were evaluated for different sowing dates during the spring/summer season, with the indeterminate types producing higher yield than the determinate ones in all sowing date treatments applied [31]. Significant higher seed yield was also recorded by Gas [32] for indeterminate types in comparison with the determinate L. mutabilis growth type, while late direct sowing during spring resulted in a lower number of pods and seeds per plant.

Several L. mutabilis genotypes were also evaluated for their life cycle duration and growth type, as these traits are significantly related to earliness $[13,14]$ and, therefore, to the ability of L. mutabilis genotypes to escape the harsh climatic conditions prevailing at the end of the Mediterranean spring. Extensive branching types with indeterminate growth were more easily adapted and productive than the determinate types under Mediterranean climatic conditions [16]. In Spain, a tested L. mutabilis accession was damaged during winter cultivation because of low temperatures [33]. However, high genetic variability has been observed among Andean lupin genotypes regarding their plant height and branching screened under Portuguese Mediterranean conditions [34]. Recently, 23 L. mutabilis accessions subjected to molecular analysis and evaluated for Mediterranean conditions adaptability in a two-year experiment. Among them a promising indeterminate accession for high yield under Mediterranean conditions as well as a semi-determinate accession were found [35].

Given the limited published works regarding Andean lupin genotypes performance under a Mediterranean climate, during autumn/winter cultivation period and the research on applying different planting dates, in this study we hypothesized that different planting dates, during autumn/winter season under a Mediterranean climate, will affect phenological stages, agro-morphological and seed nutrient traits and in general the performance of L. mutabilis accessions with different growth types. The objectives were to evaluate six L. mutabilis accessions, to assess the effect of planting date on their 
phenology and agronomical performance and to investigate what is the suitable growing season for L. mutabilis in the studied location.

\section{Materials and Methods}

\subsection{Plant Material}

Plant material used included six L. mutabilis accessions. Among the accessions, LIB209, LIB214 and LIB223 were characterized by a prolonged indeterminate growth habit, one has been characterized as a semi-determinate genotype (LIB220) while the other two (LIB221 and LIB222) were characterized by a restricted indeterminate growth habit. Two commercial cultivars of Mediterranean origin species were also used, one of L. albus (cv. Multitalia) and one of L. angustifolius (cv. Polo), as well as one L. albus cultivar of Portuguese origin under registration process (LIB224) as controls for comparing the ability of L. mutabilis to enter the successive plant developmental stages studied. Due to reduced seed availability, all seeds were put and pre-germinated on filter paper after disinfection with hypochlorite solution $20 \%$ for 2-3 min and subjected to incubation at $25^{\circ} \mathrm{C}$ temperature. When the radicles reached a length of $1 \mathrm{~cm}$, they were inoculated with Bradyrhizobium lupini (HiStick ${ }^{\circledR}$ ), transplanted to a greenhouse using as substrate peat: perlite (2:1) for a two-week growing period and then transplanted to their final position in the field.

\subsection{Experimental Design}

Two cultivation dates were applied in a field at Agricultural University of Athens (AUA), in Athens, Greece $\left(37^{\circ} 59^{\prime} 03.5^{\prime \prime} \mathrm{N}, 23^{\circ} 42^{\prime} 10.0^{\prime \prime}\right.$ E, 24 m.a.s.l.), in each of the two consecutive years. Monthly meteorological data throughout the cultivation period are presented in Figure 1. Plants were cultivated in a sandy clay loam (SCL) soil (pH: 7.86, $\mathrm{CaCO}_{3}: 17.47 \%$, O.M.: 3.22\%, N: 0.196\%, P: 45.46 ppm, $\mathrm{K}: 881.33 \mathrm{ppm}$ ). The soil in the area was classified as Regosols according to Yassoglou et al. [36]. Pre-germination application took place on 15 November 2017 and on 8 January 2018 in the first experimental year and on the 9 October 2018 and the 6 November 2018 in the second experimental year, for early and late planting treatments, respectively. A split-plot arrangement was used in a randomised complete block design (RCBD) with three replications, where planting date treatments formed the main plots, while the lupin accessions the sub-plots. A $30 \mathrm{~cm}$ row to row distance and an inter-row spacing of $20 \mathrm{~cm}$ were applied, resulting in a total number of 30 plants per plot.

\subsection{Plant Measurements}

The percentages of plants of each accession that failed to reach the flowering stage, form pods, fill and keep their pods, and produce seeds were recorded in each year under each planting treatment. Measurements were also taken regarding plant phenological traits, namely number of days from sowing seeds on filter paper to main stem beginning of flowering (DAF) and pod maturity (DMAT). Length of main inflorescence ( $\mathrm{cm}$ ) (INL), plant height from the ground to the bottom of the main stem inflorescence when the main stem started flowering $(\mathrm{cm})(\mathrm{PH})$, height from ground to the point where the first branch attaches the main stem $(\mathrm{cm})$ (H1STBR) and height from ground to the first branch's inflorescence $(\mathrm{cm})(\mathrm{H} 1 \mathrm{STBRFL})$ were also recorded.

Measurements related to pod and seed traits as well as seed yield were also taken. These included pod length $(\mathrm{cm})(\mathrm{PL})$, pod width $(\mathrm{cm})(\mathrm{PW})$, total number of pods per plant (PPPL) and total number of seeds per plant (SPPL). Number of pods and seeds in each order of inflorescences were also measured separately. Total seed weight per plant (g) was also measured and used for seed yield $\left(\mathrm{kg} \mathrm{ha}^{-1}\right)$ (SY) extrapolation. All observations and measurements were taken on 12 central plants per accession per plot. 


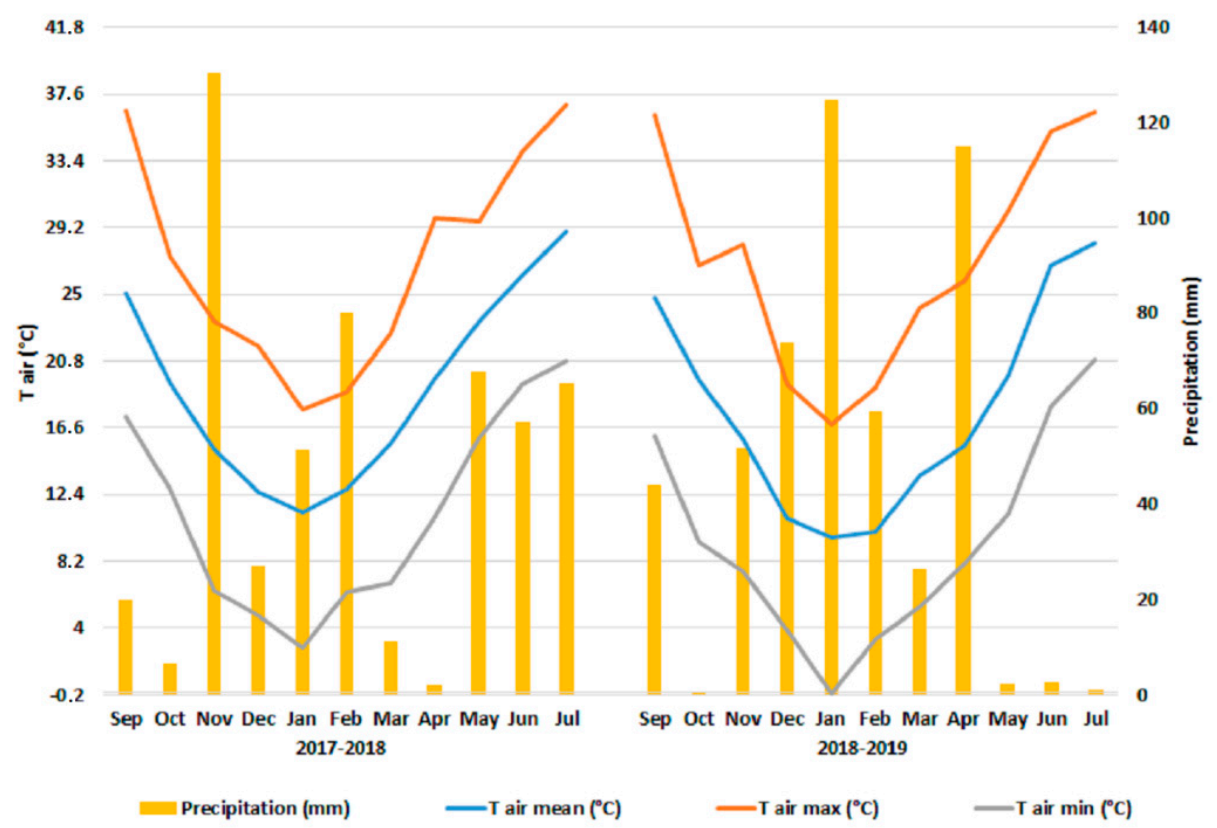

Figure 1. Mean, max and min monthly air temperature $\left({ }^{\circ} \mathrm{C}\right)$ and precipitation $(\mathrm{mm})$ during the two consecutive experimental years (2017-2018) and (2018-2019).

\subsection{Determination of Seed Nutrient Content}

Crude protein (\%), potassium $(\mathrm{K})$ and phosphorus $(\mathrm{P})$ content was determined in L. mutabilis seeds by bulking samples of 50 seeds per plot. For $\mathrm{K}$ and $\mathrm{P}$ analysis, $0.50 \mathrm{~g}$ of each sample subjected to dry ashing in a muffle furnace at $550{ }^{\circ} \mathrm{C}$ for $5 \mathrm{~h}$. Samples used to extract $\mathrm{K}$ and $\mathrm{P}$ by means of $1 \mathrm{~N} \mathrm{HCl}$. Potassium content was estimated by flame photometry (Sherwood Scientific Model 410, Cambridge, UK). Phosphorus content assessed using the Murphy-Riley method and measured photometrically as phosphor-molybdate blue complex at $880 \mathrm{~nm}$ (Biochrom Anthos Zenyth 200rt, Holliston MA, USA). For crude protein content analysis (\%), Kjeldahl-N method was used to determine the nitrogen content of L. mutabilis accessions in ground $1 \mathrm{~mm}$ size dry seed samples (FOSS Analytical LabtecTM Digestor Basic, Hilleroed, Denmark). Crude protein content was then calculated by multiplying N by the factor 6.25 (FOSS Protein Analyzer 8400 Kjeltec, Hilleroed, Denmark). Chemical composition analysis was carried out in duplicate.

\subsection{Statistical Analysis}

The statistical analysis was performed separately for the two consecutive experimental years, because the late planting dates were substantially different between the two years, and as a result, separate analysis allowed for better interpretation of the results. Residuals of all studied traits, after square-root transformation applied for INL, DAF, PPPL, SPPL and logarithm (log) transformation applied for PH, H1STBR, H1STBRFL and SY, subjected to normality test as well as checked for their homoscedasticity for each of the two experimental years. Analysis of variance (ANOVA) for split-plot design was, therefore, applied for field and for nutrient traits studied for each experimental year, followed by Tukey's (honest significant difference, HSD) $(p \leq 0.05)$ means comparison method, using a STATGRAPHICS Centurion statistical package [37]. Spearman's rank correlation coefficients were performed, using the initial data obtained for traits that were not following a normal distribution, for each experimental year, using the software package STATISTICA 8.0 for Windows [38]. A principal component analysis (PCA) was also conducted, in order to classify the accessions during each experimental year by using the statistical program JMP-8 [39]. For meteorological data display and column charts Microsoft Excel was used [40]. 


\section{Results}

\subsection{Phenology of Andean Lupin Accessions}

\subsubsection{Ability of Plants to Enter Phenological Stages}

Andean lupin plants ability to grow and enter the reproductive stage was similar to that of the two lupin species L. albus and L. angustifolius cultivated under Mediterranean environment (Table 1). LIB209, LIB214 and LIB221 presented low percentages of both non-flowering as well as non-podding plants taking into consideration both experimental years. Late planting date resulted in slightly increased percentages of losses during flowering and podding stages in comparison to the early one (Table 1). Late planting date, under the first experimental year, also led to higher percentages of plants with pod abscission and non-filled seeds in comparison to the early one in most accessions (Table 2). Maximum air average temperature higher than $25^{\circ} \mathrm{C}$ was recorded for April and higher than $29^{\circ} \mathrm{C}$ for May in both experimental years (Figure 1), when the plants under both planting date treatments applied were entering podding stage and filled their seeds.

\subsubsection{Plant Flowering and Pod Maturity}

A statistically significant effect of Planting date $x$ Accession interaction on days to flowering and days to pod maturity was recorded for both years. Planting date main effect was statistically significant for days to pod maturity, whereas it did not have an impact on days to flowering during both experimental years. Days to pod maturity were statistically significantly decreased under a late planting date application in both years for most of the accessions studied (Table 3). Among the accessions, LIB223 was the latest flowering accession under all treatments applied for both years except from the very late planting in the first year, while LIB221 the earliest one when planted during October/November in the second year. LIB223 and LIB214 were among the latest maturing accessions in the first and second experimental years, respectively, under the early planting treatments applied (Table 3).

\subsection{Agro-Morphological Traits}

\subsubsection{Plant Morphological Traits}

Planting date $x$ Accession interaction was statistically significant on all plant morphological traits studied, except for height from ground to the point where the first branch attaches the main stem during the second experimental year (Table S1). The effect of planting date was statistically significant only in the case of plant height and height from the ground to the first branch's inflorescence during the first experimental year and height from the ground to the point where the first branch attaches the main stem in both experimental years. The effect of Accession was statistically significant in every case while higher level of significance was recorded for planting date treatment and Planting date $x$ Accession interaction in the first experimental year in comparison to the second one for the majority of morphological traits studied (Table S1). High temperatures prevailed during flowering and podding stages and prevented plants from gaining a plant height higher than $1 \mathrm{~m}$ despite the indeterminate growth habit of most accessions.

\subsubsection{Pod Traits}

Pod length, pod width and total number of pods per plant were affected statistically significantly by the interaction of Planting date $x$ Accession in both experimental years (Table S2). However, Planting date main effect was statistically insignificant for all pod traits studied in the second year as well as for pod width in the first experimental year (Table S2). All accessions with the exception of LIB220 presented statistically significantly lower total number of pods per plant under a late planting date in the first year, whereas in the second experimental year there were not statistically significant 
differences in the total number of pods per plant under early and late planting date, except in the case of LIB223 (Table S2).

The number of pods of main inflorescence constituted the main proportion of the total number of pods for the majority of L. mutabilis accessions expressed as sum of all pods produced in 36 plants measured per accession per treatment and year (Figure 2). Furthermore, only few accessions produced pods in the 2nd order inflorescences, while none of the accessions studied produced pods of $3 \mathrm{rd}$ order or higher (Figure 2) due to high temperatures prevailed during flowering and podding stage.

Table 1. Percentages (\%) of plants of each accession/cultivar studied across the three replications, for the two planting date treatments and during two consecutive experimental years (2017-2018) and (2018-2019) that failed to flower and form pods.

\begin{tabular}{cccccc}
\hline \multirow{2}{*}{ Accession/Cultivar } & $\begin{array}{c}\text { Planting Date } \\
\text { Treatment }\end{array}$ & \multicolumn{2}{c}{ Plants without Flowers (\%) } & \multicolumn{2}{c}{ Plants without Pods (\%) } \\
\cline { 3 - 6 } & & $\mathbf{2 0 1 7 - 2 0 1 8}$ & $\mathbf{2 0 1 8 - 2 0 1 9}$ & $\mathbf{2 0 1 7 - 2 0 1 8}$ & $\mathbf{2 0 1 8 - 2 0 1 9}$ \\
\hline \multirow{2}{*}{ cv. Multitalia } & Early & 2.78 & 0.00 & 5.56 & 5.56 \\
& Late & 2.78 & 0.00 & 16.67 & 2.78 \\
cv. Polo & Early & 0.00 & 5.56 & 0.00 & 22.22 \\
& Late & 2.78 & 11.11 & 13.89 & 36.11 \\
LIB209 & Early & 0.00 & 0.00 & 0.00 & 2.78 \\
& Late & 0.00 & 8.33 & 8.33 & 13.89 \\
LIB214 & Early & 0.00 & 0.00 & 0.00 & 0.00 \\
& Late & 0.00 & 0.00 & 0.00 & 0.00 \\
LIB220 & Early & 0.00 & 2.78 & 0.00 & 16.67 \\
& Late & 8.33 & 2.78 & 13.89 & 22.22 \\
LIB221 & Early & 0.00 & 0.00 & 0.00 & 0.00 \\
& Late & 2.78 & 2.78 & 19.44 & 11.11 \\
LIB222 & Early & 0.00 & 2.78 & 0.00 & 13.89 \\
& Late & 16.67 & 0.00 & 22.22 & 13.89 \\
LIB223 & Early & 2.78 & 0.00 & 2.78 & 8.33 \\
& Late & 5.56 & 2.78 & 5.56 & 11.11 \\
LIB224 & Early & 0.00 & 0.00 & 0.00 & 0.00 \\
& Late & 0.00 & 0.00 & 2.78 & 2.78 \\
\hline
\end{tabular}

Table 2. Percentages (\%) of plants of each accession/cultivar studied across the three replications, for the two planting date treatments and during two consecutive experimental years (2017-2018) and (2018-2019) that failed to keep and fill their pods and produce seeds.

\begin{tabular}{cccccc}
\hline \multirow{3}{*}{ Accession/Cultivar } & $\begin{array}{c}\text { Planting Date } \\
\text { Treatment }\end{array}$ & $\begin{array}{c}\text { Plants with Empty Pods } \\
\text { or Pod Abscission (\%) }\end{array}$ & \multicolumn{2}{c}{ Plants without Seeds (\%) } \\
\cline { 3 - 6 } & & $\mathbf{2 0 1 7 - 2 0 1 8}$ & $\mathbf{2 0 1 8 - 2 0 1 9}$ & $\mathbf{2 0 1 7 - 2 0 1 8}$ & $\mathbf{2 0 1 8 - 2 0 1 9}$ \\
\hline \multirow{2}{*}{ cv. Multitalia } & Early & 5.56 & 5.56 & 5.56 & 5.56 \\
& Late & 16.67 & 2.78 & 33.33 & 2.78 \\
cv. Polo & Early & 0.00 & 27.78 & 0.00 & 50.00 \\
& Late & 38.89 & 63.89 & 52.78 & 63.89 \\
LIB209 & Early & 0.00 & 19.44 & 0.00 & 22.22 \\
& Late & 13.89 & 16.67 & 19.44 & 29.44 \\
LIB214 & Early & 0.00 & 5.56 & 2.78 & 5.56 \\
& Late & 16.67 & 11.11 & 16.67 & 11.11 \\
LIB220 & Early & 8.33 & 25.00 & 8.33 & 25.00 \\
& Late & 33.33 & 22.22 & 47.22 & 44.44 \\
LIB221 & Early & 0.00 & 19.44 & 0.00 & 19.44 \\
& Late & 22.22 & 16.67 & 36.11 & 16.67 \\
LIB222 & Early & 2.78 & 27.78 & 2.78 & 41.67 \\
& Late & 50.00 & 13.89 & 61.11 & 27.78 \\
LIB223 & Early & 2.78 & 44.44 & 8.33 & 52.78 \\
& Late & 5.56 & 16.67 & 8.33 & 16.67 \\
LIB224 & Early & 8.33 & 13.89 & 8.33 & 13.89 \\
& Late & 5.56 & 2.78 & 5.56 & 2.78 \\
\hline
\end{tabular}


Table 3. Number of days to flowering (DAF) and pod maturity (DMAT) for L. mutabilis accessions, under an early or a late planting date, for each one of the two consecutive experimental years (2017-2018) and (2018-2019).

\begin{tabular}{|c|c|c|c|c|c|}
\hline \multirow{2}{*}{ Accession } & \multirow{2}{*}{$\begin{array}{l}\text { Planting Date } \\
\text { Treatment }\end{array}$} & \multicolumn{2}{|c|}{ DAF } & \multicolumn{2}{|c|}{ DMAT } \\
\hline & & $2017-2018$ & 2018-2019 & 2017-2018 & 2018-2019 \\
\hline \multirow[t]{2}{*}{ LIB209 } & Early & $103.36 \mathrm{c}$ & $126.25 \mathrm{e}$ & $176.14 \mathrm{c}$ & $199.52 \mathrm{~b}$ \\
\hline & Late & $92.97 \mathrm{ef}$ & $125.41 \mathrm{e}$ & $133.78 \mathrm{ij}$ & $165.42 \mathrm{i}$ \\
\hline \multirow[t]{2}{*}{ LIB214 } & Early & 104.92 c & 130.36 de & $185.11 \mathrm{~b}$ & $204.53 \mathrm{a}$ \\
\hline & Late & $98.17 \mathrm{~d}$ & $125.94 \mathrm{e}$ & $145.25 \mathrm{~g}$ & $172.92 \mathrm{~g}$ \\
\hline \multirow[t]{2}{*}{ LIB220 } & Early & $110.75 \mathrm{~b}$ & $138.04 \mathrm{bc}$ & $168.17 \mathrm{~d}$ & $198.89 \mathrm{~b}$ \\
\hline & Late & $92.01 \mathrm{ef}$ & $135.26 \mathrm{~cd}$ & $134.93 \mathrm{i}$ & $170.04 \mathrm{~h}$ \\
\hline \multirow[t]{2}{*}{ LIB221 } & Early & $89.86 \mathrm{f}$ & $110.36 \mathrm{~g}$ & $151.36 \mathrm{f}$ & $186.44 \mathrm{e}$ \\
\hline & Late & 94.02 def & $116.41 \mathrm{f}$ & $135.85 \mathrm{i}$ & $160.94 \mathrm{j}$ \\
\hline \multirow[t]{2}{*}{ LIB222 } & Early & $104.61 \mathrm{c}$ & $135.44 \mathrm{~cd}$ & 155.17 e & $193.26 \mathrm{~d}$ \\
\hline & Late & $95.23 \mathrm{de}$ & $138.08 \mathrm{bc}$ & $142.80 \mathrm{~h}$ & $172.64 \mathrm{~g}$ \\
\hline \multirow[t]{2}{*}{ LIB223 } & Early & $119.72 \mathrm{a}$ & $145.64 \mathrm{a}$ & $203.33 \mathrm{a}$ & $195.89 \mathrm{c}$ \\
\hline & Late & $92.55 \mathrm{ef}$ & $141.56 \mathrm{ab}$ & $132.34 \mathrm{j}$ & $178.94 \mathrm{f}$ \\
\hline \multicolumn{6}{|c|}{ Main Effects } \\
\hline \multicolumn{2}{|c|}{ Early } & 105.54 & 131.01 & $173.21 \mathrm{a}$ & $196.42 \mathrm{a}$ \\
\hline \multicolumn{2}{|c|}{ Late } & 94.16 & 130.44 & $137.49 \mathrm{~b}$ & $170.15 \mathrm{~b}$ \\
\hline \multicolumn{2}{|c|}{ LIB209 } & $98.17 \mathrm{c}$ & $125.83 \mathrm{c}$ & $154.96 \mathrm{c}$ & $182.47 \mathrm{c}$ \\
\hline \multicolumn{2}{|c|}{ LIB214 } & $101.54 \mathrm{~b}$ & $128.15 \mathrm{c}$ & $165.18 \mathrm{~b}$ & $188.72 \mathrm{a}$ \\
\hline \multicolumn{2}{|c|}{ LIB220 } & $101.38 \mathrm{~b}$ & $136.65 \mathrm{~b}$ & $151.55 \mathrm{~d}$ & $184.47 \mathrm{~b}$ \\
\hline \multicolumn{2}{|c|}{ LIB221 } & $91.94 \mathrm{~d}$ & $113.39 \mathrm{~d}$ & $143.61 \mathrm{f}$ & $173.69 \mathrm{~d}$ \\
\hline \multicolumn{2}{|c|}{ LIB222 } & $99.92 b c$ & $136.76 \mathrm{~b}$ & $148.99 \mathrm{e}$ & $182.95 \mathrm{c}$ \\
\hline \multicolumn{2}{|c|}{ LIB223 } & $106.14 \mathrm{a}$ & $143.60 \mathrm{a}$ & $167.84 \mathrm{a}$ & $187.41 \mathrm{a}$ \\
\hline \multicolumn{6}{|c|}{ Significance } \\
\hline \multicolumn{2}{|c|}{ Planting date } & n.s. & n.s. & $* * *$ & ** \\
\hline \multicolumn{2}{|c|}{ Accession } & $* * *$ & $* * *$ & $* * *$ & $* * *$ \\
\hline \multicolumn{2}{|c|}{ Planting date $x$ Accession } & $* * *$ & $* * *$ & $* * *$ & $* * *$ \\
\hline
\end{tabular}

n.s.: non-significant, ${ }^{* *}:$ significant at the 0.01 level, ${ }^{* * *}$ : significant at the 0.001 level. Means in columns with different letters are statistically significantly different at $p \leq 0.05$ using Tukey's (HSD).

\subsubsection{Seed Traits and Yield}

In the first experimental year, the total number of seeds per plant and seed yield production $\left(\mathrm{kg} \mathrm{ha}^{-1}\right)$ were statistically significantly increased under an early planting date application compared to the late planting treatment. Contrary to the first experimental year, in the second experimental year there was not a statistically significant effect of Planting date on total seed number and seed yield (Table 4). However, a statistically significant effect of Planting date $\mathrm{x}$ Accession interaction on total number of seeds per plant and seed yield was found. All L. mutabilis accessions performed higher seed yield under the early planting date in comparison to the very late planting date applied in the first experimental year. In the second experimental year, only LIB223 presented statistically significant lower seed yield production under late planting date application in comparison to the early one. Interestingly, some of the accessions, named LIB209, LIB214 and LIB221 presented increased seed yield under late planting application in the second experimental year, however they were not statistically significant (Table 4). The number of seeds of the main stem constituted the higher proportion of total number of seeds (Figure 3) and contributed more in most cases in total seed production than seeds produced by the 1st and 2nd orders of inflorescence. 


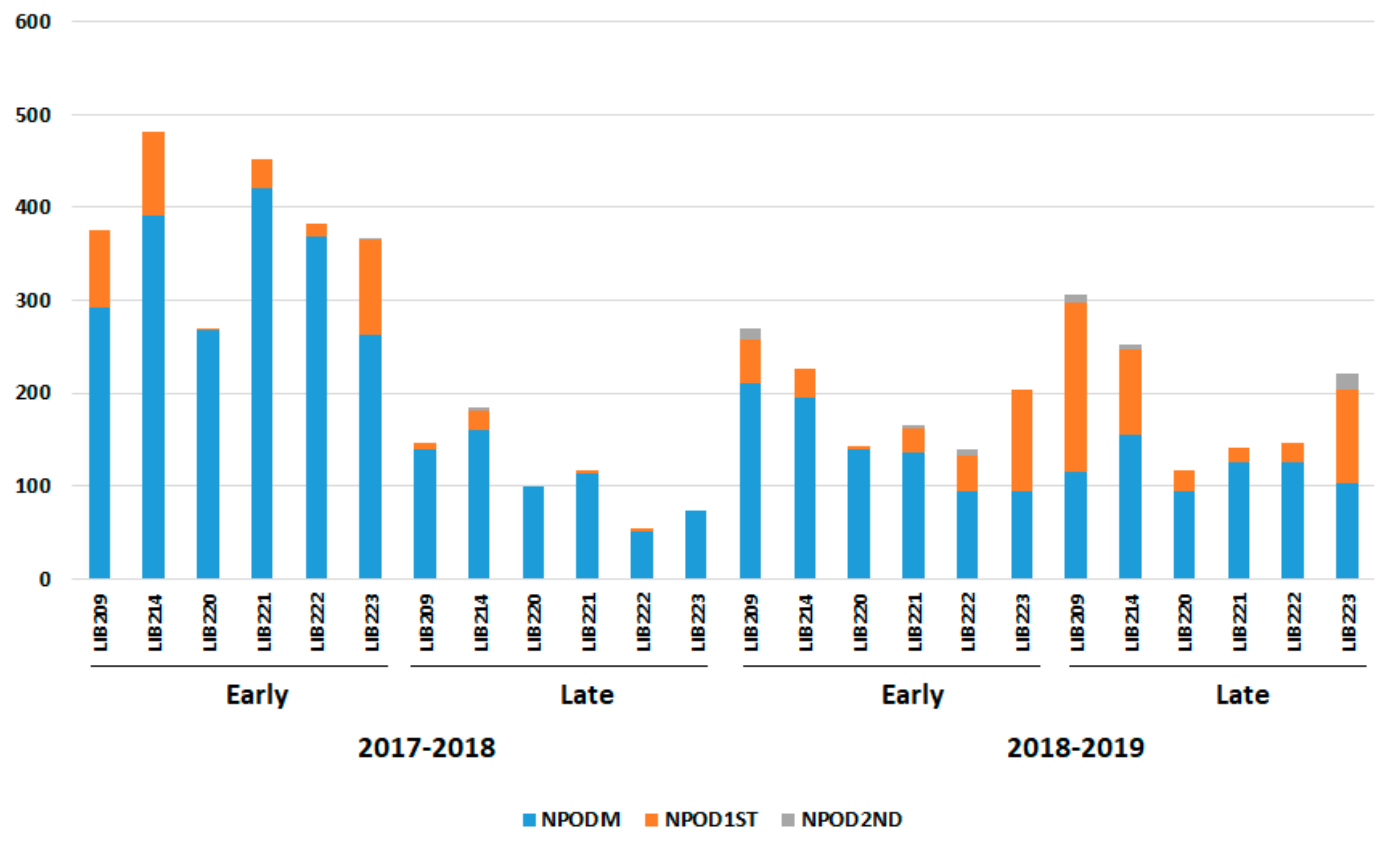

Figure 2. Total number of pods (NPODM), number of pods in first order branch (NPOD1ST) and number of pods in second order branch (NPOD2ND) from all plants of each L. mutabilis accession used, under an early or a late planting date treatment in each of the two consecutive experimental years (2017-2018) and (2018-2019).

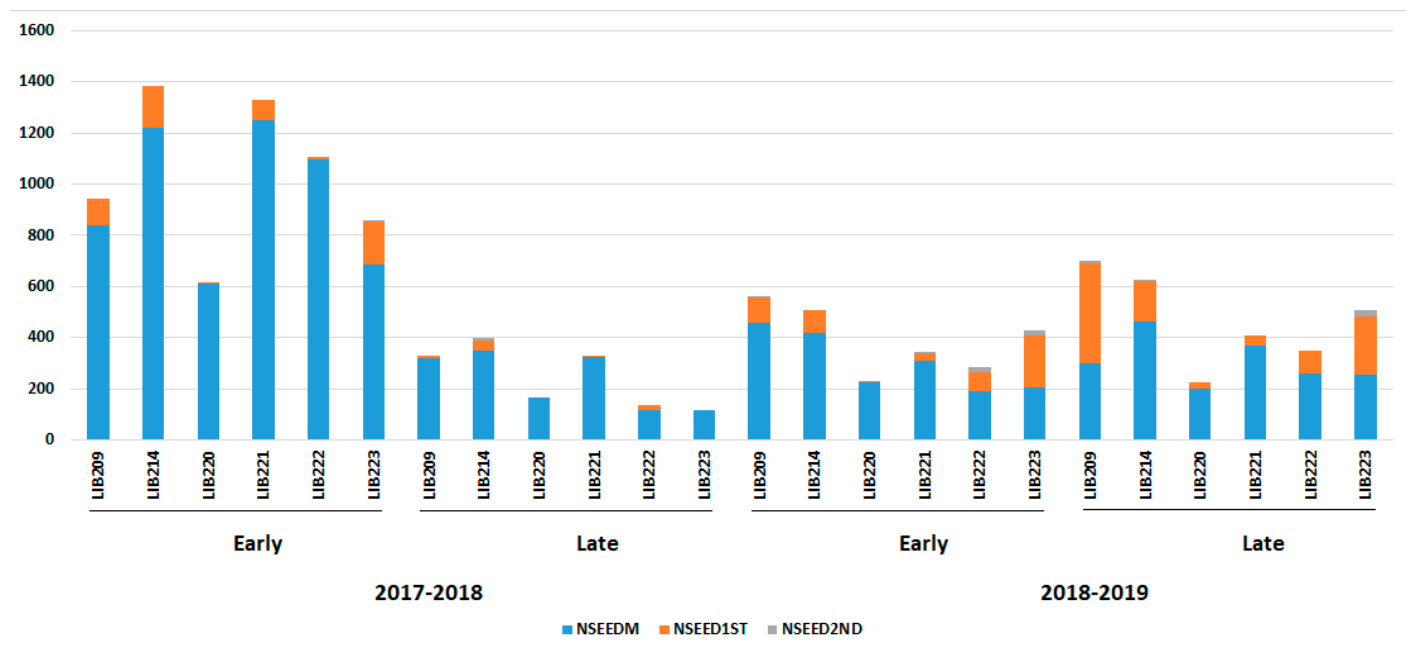

Figure 3. Total number of seeds (NSEEDM), number of seeds in first order branch (NSEED1ST) and number of seeds in second order branch (NSEED2ND) from all plants of each L. mutabilis accession used under an early or a late planting date treatment in each of the two consecutive experimental years (2017-2018) and (2018-2019). 
Table 4. Total number of seeds per plant (SPPL) and seed yield (SY) $\left(\mathrm{kg} \mathrm{ha}^{-1}\right)$ of L. mutabilis accessions, under an early or a late planting date, for each one of the two consecutive experimental years (2017-2018) and (2018-2019).

\begin{tabular}{|c|c|c|c|c|c|}
\hline \multirow{2}{*}{ Accession } & \multirow{2}{*}{$\begin{array}{c}\text { Planting Date } \\
\text { Treatment }\end{array}$} & \multicolumn{2}{|c|}{ SPPL } & \multicolumn{2}{|c|}{ SY } \\
\hline & & $2017-2018$ & 2018-2019 & $2017-2018$ & 2018-2019 \\
\hline \multirow[t]{2}{*}{ LIB209 } & Early & $26.14 \mathrm{bc}$ & $19.83 \mathrm{abc}$ & $770.34 \mathrm{~b}$ & $327.38 \mathrm{bc}$ \\
\hline & Late & $11.55 \mathrm{de}$ & $23.64 \mathrm{ab}$ & $165.19 \mathrm{~cd}$ & $396.34 \mathrm{~b}$ \\
\hline \multirow[t]{2}{*}{ LIB214 } & Early & $39.44 \mathrm{a}$ & $15.04 \mathrm{abcd}$ & $1085.88 \mathrm{a}$ & $318.09 \mathrm{bc}$ \\
\hline & Late & $13.33 \mathrm{de}$ & $19.56 \mathrm{abc}$ & $298.48 \mathrm{~cd}$ & $418.35 \mathrm{~b}$ \\
\hline \multirow[t]{2}{*}{ LIB220 } & Early & 18.36 cde & $7.80 \mathrm{~d}$ & $468.42 \mathrm{c}$ & $174.66 \mathrm{c}$ \\
\hline & Late & $9.40 \mathrm{e}$ & $9.39 \mathrm{~cd}$ & $135.28 \mathrm{~d}$ & $161.72 \mathrm{c}$ \\
\hline \multirow[t]{2}{*}{ LIB221 } & Early & $36.94 \mathrm{a}$ & $11.41 \mathrm{~cd}$ & $895.91 \mathrm{ab}$ & $147.04 \mathrm{c}$ \\
\hline & Late & $15.54 \mathrm{de}$ & $13.63 \mathrm{bcd}$ & $233.27 \mathrm{~cd}$ & $280.94 \mathrm{bc}$ \\
\hline \multirow[t]{2}{*}{ LIB222 } & Early & $31.62 \mathrm{ab}$ & $13.29 \mathrm{bcd}$ & $475.47 \mathrm{c}$ & $166.62 \mathrm{c}$ \\
\hline & Late & $11.30 \mathrm{de}$ & $13.68 \mathrm{bcd}$ & $125.70 \mathrm{~d}$ & $161.72 \mathrm{c}$ \\
\hline \multirow[t]{2}{*}{ LIB223 } & Early & $24.40 \mathrm{bcd}$ & $25.58 \mathrm{a}$ & $721.95 \mathrm{~b}$ & $872.91 \mathrm{a}$ \\
\hline & Late & $8.51 \mathrm{e}$ & $16.98 \mathrm{abcd}$ & $157.01 \mathrm{~cd}$ & $404.70 \mathrm{~b}$ \\
\hline \multicolumn{6}{|c|}{ Main Effects } \\
\hline \multicolumn{2}{|r|}{ Early } & $29.48 \mathrm{a}$ & 15.49 & $736.33 \mathrm{a}$ & 334.45 \\
\hline \multicolumn{2}{|r|}{ Late } & $11.60 \mathrm{~b}$ & 16.15 & $185.82 \mathrm{~b}$ & 303.96 \\
\hline \multicolumn{2}{|c|}{ LIB209 } & $18.84 \mathrm{bc}$ & $21.73 \mathrm{a}$ & $467.76 \mathrm{bc}$ & $361.86 \mathrm{~b}$ \\
\hline \multicolumn{2}{|r|}{ LIB214 } & $26.39 a$ & $17.30 \mathrm{ab}$ & $692.18 \mathrm{a}$ & $368.22 \mathrm{~b}$ \\
\hline \multicolumn{2}{|r|}{ LIB220 } & $13.88 \mathrm{c}$ & $8.60 \mathrm{c}$ & $301.85 \mathrm{~d}$ & $168.19 \mathrm{c}$ \\
\hline \multicolumn{2}{|r|}{ LIB221 } & $26.24 \mathrm{a}$ & $12.52 \mathrm{bc}$ & $564.59 \mathrm{ab}$ & $213.99 \mathrm{c}$ \\
\hline \multicolumn{2}{|r|}{ LIB222 } & $21.46 \mathrm{ab}$ & $13.48 \mathrm{bc}$ & $300.58 \mathrm{~d}$ & $164.17 \mathrm{c}$ \\
\hline \multicolumn{2}{|r|}{ LIB223 } & $16.45 \mathrm{bc}$ & $21.28 \mathrm{a}$ & $439.48 \mathrm{bcd}$ & $638.81 \mathrm{a}$ \\
\hline \multicolumn{6}{|c|}{ Significance } \\
\hline \multicolumn{2}{|c|}{ Planting date } & * & n.s. & * & n.s. \\
\hline \multicolumn{2}{|c|}{ Accession } & $* * *$ & $* * *$ & $* * *$ & $* * *$ \\
\hline \multicolumn{2}{|c|}{ Planting date $x$ Accession } & $* *$ & * & $* * *$ & $* * *$ \\
\hline
\end{tabular}

n.s.: non-significant, ${ }^{*}:$ significant at the 0.05 level, ${ }^{* *}$ : significant at the 0.01 level, ${ }^{* * *}$ : significant at the 0.001 level. Means in columns with different letters are statistically significantly different at $p \leq 0.05$ by Tukey's (honest significant difference, HSD).

\subsection{Seed Nutrient Content}

The amount of crude protein (\%) content in Andean lupin seeds was affected by the interaction of Planting date $x$ Accession in both experimental years, with most of the accessions presenting a higher crude protein content under the late in comparison with the early planting date in the first year (Table S3). Only LIB223 and LIB209 presented statistically significant higher seed crude protein content under the early planting date applied in the first year. In the second experimental year, slight differentiation observed for each accession when an early or a late planting was applied (Table S3). Seed crude protein content in the first experimental year was higher in the L. mutabilis accessions LIB223 (45.40\%) and LIB209 (43.81\%) in the early sowing treatment while the lowest content was observed in LIB222 $(32.56 \%)$ under early planting date treatment (Table S3). In the first experimental year, the lowest seed potassium content $8.10 \mathrm{mg} \mathrm{g}^{-1}$ recorded in LIB214 and LIB222 under the late and early planting date treatment, respectively, while the highest content in LIB220 $\left(10.20 \mathrm{mg} \mathrm{g}^{-1}\right)$ in early sowing treatment. In the second year, seed potassium content ranged from $8.36 \mathrm{mg} \mathrm{g}^{-1}$ (LIB209) to $10.05 \mathrm{mg} \mathrm{g}^{-1}$ (LIB221) among the accessions studied (Table S3). Additionally, phosphorus seed content varied statistically significant among the L. mutabilis accessions with LIB214 resulting in the highest phosphorus content in both experimental years (Table S3). 


\subsection{Investigation of Correlations among Traits}

In the first experimental year, a significant positive correlation was observed between many traits such as plant height and length of main inflorescence, height from ground to the first branch's inflorescence, days to pod maturity, total number of pods per plant, total number of seeds per plant and seed yield ( $p<0.001$ ) (Table S4). Days to main stem flowering correlated moderately significantly and positively to days to pod maturity $(r=0.656, p<0.001)$, while days to pod maturity correlated moderately significantly and positively to the total number of pods per plant $(r=0.515, p<0.001)$. Plant height, days to pod maturity and pod length correlated moderately positively with seed yield $(p<0.001)$, while total number of pods and total number of seeds per plant correlated significantly to seed yield (Table S4). Regarding seed nutrient traits studied there were no significant correlations observed $(p<0.001)$ (Table S4).

In the second year, a moderate positive correlation was observed between plant height and height from ground to the lower first branch attached point to the main stem as well as height from ground to the first branch's inflorescence $(r=0.649$ and $r=0.576$ for both traits respectively, $p<0.001)$ (Table S5). Height from ground to the lower first branch attached point to the main stem correlated significantly positively to height from ground to the first branch's inflorescence $(r=0.740, p<0.001)$. Days to main stem flowering and days to pod maturity did not correlate statistically significantly to the total number of pods per plant. Total number of pods per plant and total number of seeds per plant correlated significantly positively with seed yield ( $r=0.770$ and $r=0.867$ for both traits respectively, $p<0.001)$ (Table S5). As in the first experimental year, there were no significant correlations observed among seed nutrient traits studied (Table S5).

\subsection{Principal Components and Classification of Andean Lupin Accessions}

PCA was performed to reduce the dimensionality of the data and to classify the accessions. The first three axes of PCA explained $79.46 \%$ of the total variation presented in the first experimental year. Plant height, length of main inflorescence, days to pod maturity, pod length, total number of pods per plant, total number of seeds per plant as well as seed yield were related to the first principal component (PC1,51.64\%). Height from ground to the point where the first branch attaches the main stem, height from ground to the first branch's inflorescence and days to main stem flowering contributed to the second principal component (PC2, 18.04\%) (Table 5; Figure 4a). Seed crude protein and phosphorus content were related to the third principal component (PC3, 9.78\%) (Table 5).

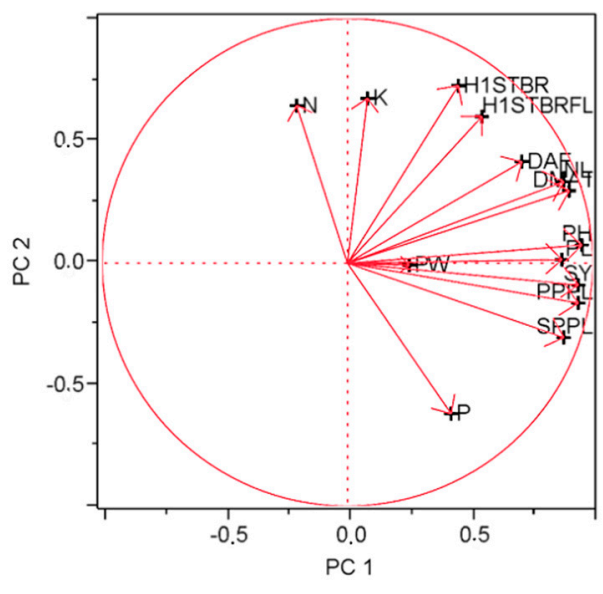

(a)

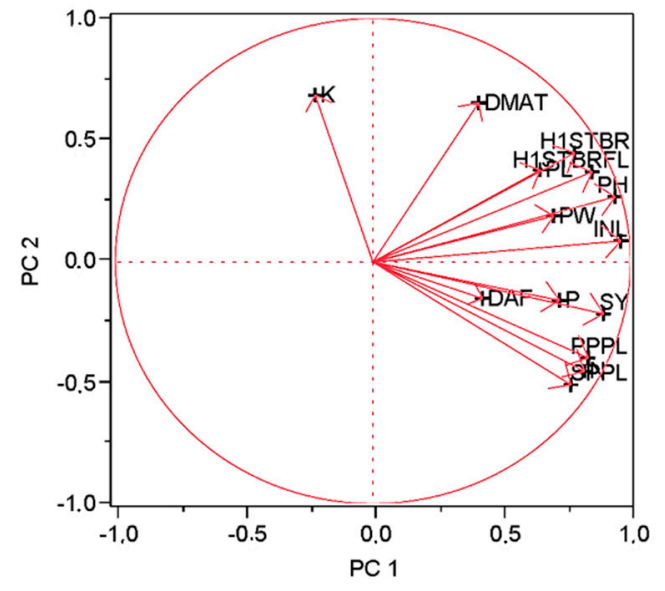

(b)

Figure 4. Trait loadings of principal component analysis (PCA) during (a) first experimental year and (b) second experimental year. 
Table 5. Principal component coefficients (PC) based on the traits studied for each one of the two experimental years.

\begin{tabular}{|c|c|c|c|c|c|c|}
\hline \multirow[t]{2}{*}{ Trait } & \multicolumn{3}{|c|}{$2017-2018$} & \multicolumn{3}{|c|}{ 2018-2019 } \\
\hline & PC1 & PC2 & PC3 & PC1 & PC2 & PC3 \\
\hline $\mathrm{PH}^{1}$ & 0.848 & 0.419 & 0.156 & 0.634 & 0.735 & 0.122 \\
\hline INL $^{2}$ & 0.841 & 0.461 & -0.169 & 0.736 & 0.627 & 0.005 \\
\hline H1STBR $^{3}$ & 0.101 & 0.935 & -0.121 & 0.309 & 0.925 & -0.018 \\
\hline H1STBRFL $^{4}$ & 0.193 & 0.893 & 0.002 & 0.419 & 0.882 & -0.029 \\
\hline DAF $^{5}$ & 0.414 & 0.775 & 0.103 & 0.188 & 0.455 & -0.593 \\
\hline DMAT $^{6}$ & 0.714 & 0.627 & 0.073 & -0.142 & 0.920 & -0.011 \\
\hline $\mathbf{P L}^{7}$ & 0.928 & 0.174 & -0.013 & 0.542 & 0.371 & 0.603 \\
\hline $\mathrm{PW}^{8}$ & 0.399 & -0.111 & -0.171 & 0.709 & 0.222 & 0.571 \\
\hline PPPL $^{9}$ & 0.872 & 0.235 & 0.316 & 0.844 & 0.251 & -0.297 \\
\hline SPPL ${ }^{10}$ & 0.850 & 0.104 & 0.389 & 0.917 & 0.026 & -0.194 \\
\hline SY 11 & 0.923 & 0.218 & 0.182 & 0.914 & 0.263 & 0.026 \\
\hline Crude protein & -0.023 & 0.077 & -0.832 & 0.880 & 0.170 & -0.283 \\
\hline Potassium & -0.003 & 0.486 & -0.473 & -0.265 & 0.008 & 0.903 \\
\hline Phosphorus & 0.185 & 0.057 & 0.902 & 0.772 & 0.159 & 0.129 \\
\hline
\end{tabular}

\footnotetext{
${ }^{1}$ PH: plant height, ${ }^{2}$ INL: length of main inflorescence, ${ }^{3}$ H1STBR: height from ground to the lower first branch attached point to the main stem, ${ }^{4}$ H1STBRFL: height from ground to the first branch's inflorescence, ${ }^{5}$ DAF: days to main stem flowering, ${ }^{6}$ DMAT: days to pod maturity of the plants, ${ }^{7}$ PL: pod length, ${ }^{8}$ PW: pod width, ${ }^{9}$ PPPL: total number of pods per plant, ${ }^{10}$ SPPL: total number of seeds per plant, ${ }^{11}$ SY: seed yield. Traits related most with each axis are presented in Bold.
}

In the second experimental year, the first three axes of PCA, explained $85.61 \%$ of the total variation. Length of main inflorescence, pod width, total number of pods per plant, total number of seeds per plant, seed yield, seed crude protein and phosphorus content related to the first principal component (PC1, 55.38\%). Plant height, height from ground to the point where the first branch attaches the main stem, height from ground to the first branch's inflorescence and days to pod maturity contributed to the second principal component (PC2, 15.74\%) (Table 5; Figure 4b). Seed potassium content related to the third principal component (PC3, 14.49\%) (Table 5). Length of main inflorescence, total number of pods per plant, total number of seeds per plant and seed yield were the traits that contributed the most in the first principal axis during both experimental years (Table 5; Figure 4a,b).

Andean lupin accessions formed two separate groups in the first experimental year based mainly on the seed yield-related traits studied, in which all the accessions were found to be more productive under the early planting date applied (Figure 5, Table 4). In contrast to the first year, in the second experimental year an analogous classification was not observed (Figure 6). However, LIB209, LIB214 and LIB223 accessions both under an early or a late planting date treatment were differentiated from the other accessions (Figure 6). 




Figure 5. Principal component analysis (PCA) of the six L. mutabilis accessions (ACC CODE) in the first experimental year (2017-2018) based on traits studied and projection of the traits studied. The six L. mutabilis accessions are indicated by different symbols, while early and late planting date treatments are indicated by red and blue symbols' color, respectively.

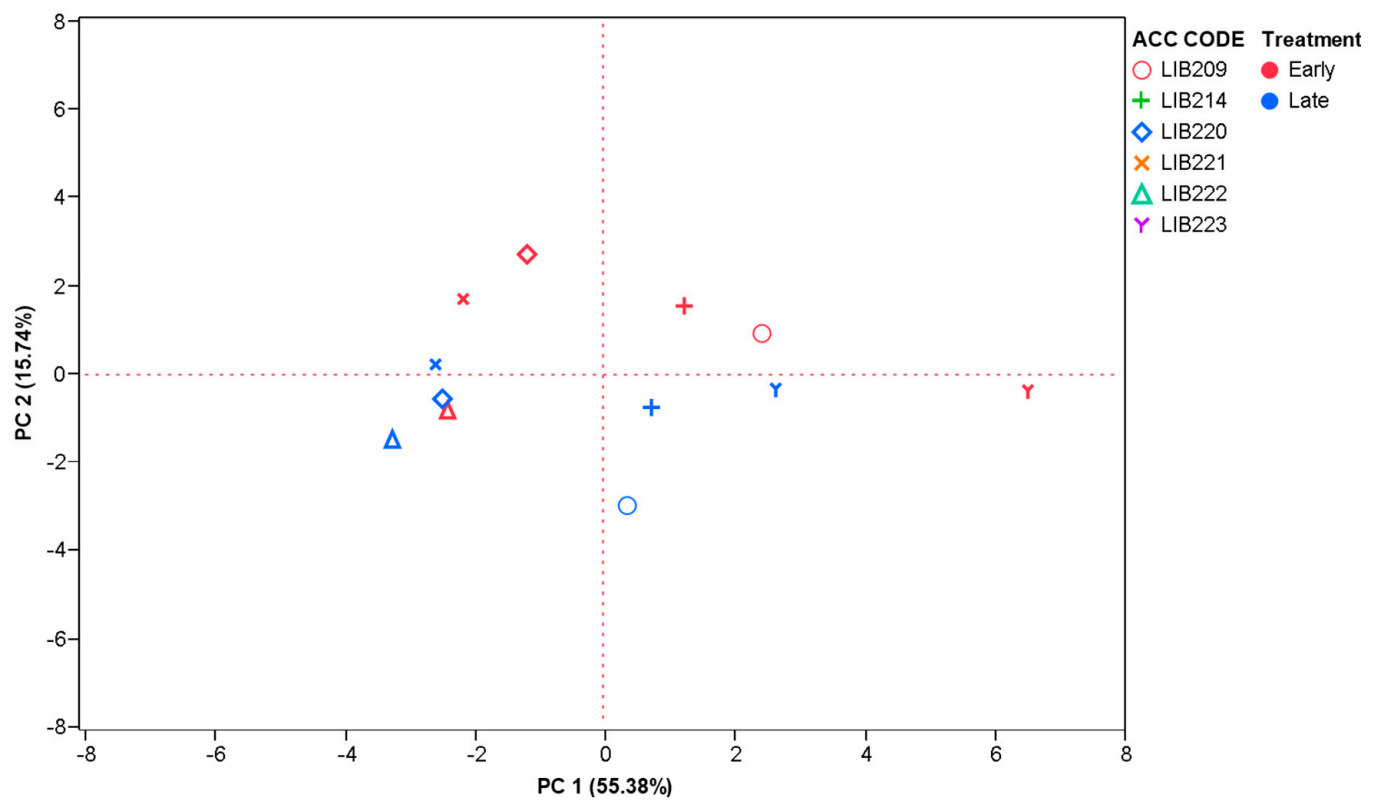

Figure 6. Principal component analysis (PCA) of the six L. mutabilis accessions (ACC CODE) in the second experimental year (2018-2019) based on traits studied and projection of the traits studied. The six L. mutabilis accessions are indicated by different symbols, while early and late planting date treatments are indicated by red and blue symbols' color, respectively.

\section{Discussion}

Andean lupin accessions, using transplantation due to limited plant material, were evaluated under an autumn/winter cultivation period, showed an overall ability to enter the different plant phenological stages under a typical Mediterranean climate of Greece and the high alkaline soil that characterizes large areas in the region. Despite the fact that the area is characterized by mild winters, an autumn planting could be a limiting factor, especially for indeterminate growth accessions that need vernalization [26,41] in contrast to the determinate accessions [41]. However, only a few plants did not initiate their meristems and enter the flowering stage regardless of their growth type. 
In the region, high air temperatures over $25-28{ }^{\circ} \mathrm{C}$ prevail at the end of spring and drought conditions are common during the late spring to summer period. These conditions increase the pollen sterility of lupins [10], while air temperatures over $33^{\circ} \mathrm{C}$ induce flower and pod abortion [42,43], leading to increased seed yield losses that reach even 59-73\% [14]. High air temperature prevailed during the flowering $\left(>25^{\circ} \mathrm{C}\right)$ and podding stage $\left(>29^{\circ} \mathrm{C}\right)$ in both years and low rainfall regimes from May to July during the second experimental year negatively affected all accessions and led to increased percentages of plants with unfilled seeds and pods abscission, especially under the very late planting treatment applied in the first experimental year. It is crucial, therefore, to screen and select genotypes with increased drought tolerance [15] that can express various tolerance mechanisms [44]. Plants under all treatments due to heat stress were not able to produce pods and seeds of a third or a higher order of branches. The same observation has also been mentioned by Neves-Martins et al. [16] who reported that $95 \%$ of the total production of L. mutabilis was due to its main and first order inflorescences under Portuguese climatic conditions and by Adhikari et al. [45] in L. angustifolius.

Life-cycle shrinkage, fewer days to pod maturity and hindered plant morphological traits such as plant height, decreased total pod and seed number per plant as well as reduced seed yield recorded in most accessions under late planting treatments. Shorter vegetative growth and faster pod-filling periods, as well as reduced seed yield production, have also been reported in many legume species under heat stress [46]. In addition, a significant effect of planting treatment on the number of days from sowing to pod maturity has also previously been mentioned by López-Bellido et al. [47], Keeve et al. [48] and Christiansen and Jørnsgård [49] in L. albus and L. angustifolius accessions. In the second experimental year, an accession effect on most traits was evident, while an earlier planting date (in October) did not lead to enhancement of yield. Traits like plant height, days to maturity and seed yield primarily contributed to the first two axes indicating their high impact on lupin differentiation [50]. Planting from late October to November is, therefore, advised in the area, while among the four-planting date/year applications, the early treatment of the first experimental year resulted in enhanced plant growth and higher seed yield production and, therefore, was considered as the most favorable. Planting from October to November has also been proposed for Portuguese Mediterranean conditions [16,51].

Strong positive correlations were observed between plant height and height from ground to the first branch's infloresence, days to pod maturity, total number of pods per plant, total number of seeds per plant and seed yield indicating the importance of growth type selection to breed for seed yield [15]. The importance of correlation of plant architecture to phenological and agronomical traits and the feasibility of breeding for favorable genotypes aiming to increase yield production has been previously underlined by Römer and Jahn-Deesbach [18], Hardy et al. [26] and Guilenge et al. [35].

The accessions with long life cycle and indeterminate growth (LIB209, LIB214 and LIB223) were affected mostly by the unfavorable climatic conditions at the end of the summer that prevented them from producing pods and seeds of a third or higher order of branches. The results reinforce the view that in Southern Europe Andean lupin cultivation should focus on seed production [16] as large biomass production is inhibited by drought and high temperatures [52]. The L. mutabilis accessions evaluated yielded lower than the $1.5 \mathrm{tha}^{-1}$ on average that is considered as desirable for cultivation on a commercial scale and was achieved under European climatic conditions [18,31,35], thus more research is needed to increase yield in Greece. However, a yield of $130 \mathrm{~kg} \mathrm{ha}^{-1}$ in Ecuador is considered common [53].

The very low yield that was recorded in Andean lupin accessions could be due to the high percentage of soil calcium carbonate and $\mathrm{pH}$ value, as their negative impact on lupins is very well documented [54-56]. Planting density applied in our experiment was also very low (16.6 plants per $\mathrm{m}^{2}$ ) due to the availability of limited seed lots. Pszczółkowska et al. [31] applied seed rates of 60, 90, 120 per $\mathrm{m}^{2}$, leading to higher seed yield in comparison to our experiment. A denser planting is, therefore, suggested, especially for semi-determinate and indeterminate genotypes which are characterized by a restricted growth and a tendency to produce pods only in the main stem, resulting therefore in lower yield production in comparison to the indeterminate growth accessions as in white lupin [57]. 
Seed yield extrapolation depends also on the calculation method followed and can also lead to discrepancy among seed yield obtained among studies [18]. Calculation of seed yield depending on seed yield per plant, as implemented in this study, usually results in higher seed yield $\left(\mathrm{kg} \mathrm{ha}^{-1}\right)$ values [58].

Indeterminate accessions with long life cycle performed better than the restricted indeterminate type accessions (LIB221, LIB222) and the semi-determinate accession (LIB220) tested in the three less favorable planting date/year combinations. Semi-determinate and determinate accessions proposed as preferable $[13,35,59]$ were not considered as suitable for cultivation in the area. LIB223 was the indeterminate accession that was affected mostly by late planting, probably due to its very late flowering and delay in entering production. A long life-cycle indeterminate growth type with early flowering, which does not develop all branches and flowers at the same time, can compensate better for abiotic stresses during the cultivation period [42,60]. LIB209 and LIB214 are, therefore, considered as most promising for cultivation in the area. However, the heritability of flowering had been found to be low for L. mutabilis in comparison to other lupin species [26,35].

Attempting to predict developmental stages, except temperature effect and genotype, daylength effect should be also considered, as it is primarily responsible for lengthening or shortening time period from sowing to flowering and to maturity [47,48,61] and controlling annual legumes phenology [62]. The impact of the photoperiod should also be investigated, as it seems to influence various lupin species $[41,45,63,64]$ and relative references are contradictory regarding L. mutabilis genotypes response to photoperiod $[14,41,65-68]$. Planting treatment affected statistically significantly the number of days to pod maturity whereas it did not influence the number of days to flowering. Genotype was the main factor that affected the entrance to flowering stage. Therefore, temperature and photoperiod needs should be assessed separately for each developmental stage as proposed by Myers et al. [69].

Further investigation regarding heat units (HU) for each accession and for each developmental stage would also be helpful in the selection of appropriate Andean lupin genotypes, as an early flowering and rapid pod filling period genotype could escape terminal drought and high temperatures [16]. However, rapid pod filling is accompanied by poor seed filling, as the availability of nitrogen and carbon assimilates to seeds is restricted under drought [70,71] and high temperatures occurrence [72], due to hampered photosynthesis [71]. A shorter period of seed filling led to a smaller seed size of white lupins [73] as well as to reduced seed yield of narrow-leafed lupins [71]. Therefore, an early pod filling genotype should be accompanied by a fast and high transfer of accumulates in seeds [74].

Andean lupin seed macronutrient traits studied, were not affected significantly by the planting treatments applied, with the exception of seed crude protein content in the first experimental year under the late planting treatment. The higher seed crude protein content under the very late planting treatment of the first year indicates a higher mobilization of nitrogen from stems to seeds, for most accessions, during pod formation until maturity, compared to the early planting treatment, due to higher temperatures that occurred during this period, as described previously for different crops by Gonzalez-Dugo et al. [75]. On the contrary, LIB223 and LIB209 presented a statistically significant lower amount of seed protein content under late planting in the first year. Defining plant nitrogen nutrition status is complicated because soil and plant biological processes directly interfere with $\mathrm{N}$ availability and uptake [75]. Further investigation is, therefore, needed regarding Andean lupin accessions capacity for nitrogen assimilation and remobilization [75], differentiation in high temperature and drought response mechanisms [76-80] as well as soil characteristics that can affect nitrogen uptake and mobilization [81].

Crude protein values obtained, were within the range of values $32 \%$ to $52.6 \%$ reported in previous studies [13,82]. Indeterminate growth accessions did not present higher seed crude protein content than the semi-determinate and the restricted intermediate growth types. Our results display a discrepancy with those presented from Pszczółkowska et al. [31] that reported higher seed protein content of an indeterminate genotype (38\%) than a determinate one (35\%), while are in consistency with Adomas et al. [21] that reported no differences regarding indeterminate and determinate Andean 
lupin genotypes. These differences are probably due to the different germplasm used as statistically significant differences among accessions were recorded during our study.

Seed potassium values obtained were lower than those reported by Carvajal-Larenas et al. [82] for Andean lupin raw seeds that ranged from 11.30 to $14.00 \mathrm{mg} \mathrm{g}^{-1}$, while a higher potassium content was found than the $7.6 \mathrm{mg} \mathrm{g}^{-1}$ on average reported by Adomas et al. [21]. Differentiations in seed potassium content could be attributed to the use of different analytical methods [82] and other conditions. Phosphorus content was lower than the average of $7.53 \mathrm{mg} \mathrm{g}^{-1}$ for Andean lupin that has been previously reported by Carvajal-Larenas et al. [82] and the $5.65 \mathrm{mg} \mathrm{g}^{-1}$ on average value obtained by Adomas et al. [21]. A diminished amount of seed phosphorus was expected in this present study, as in calcareous and alkaline soils phosphorus solubility is hampered [83]. Overall, statistically significant differences were recorded among accessions potassium and phosphorus content, regardless of their growth habit, as LIB220, LIB221 and LIB222 presented a more determinate growth habit while LIB209, LIB214 and LIB223 presented a long life-cycle indeterminate growth habit. Pszczółkowska et al. [31] also recorded no differences in potassium and phosphorus seed content between a determinate and an indeterminate Andean lupin morphotype.

\section{Conclusions}

A statistically significant effect of planting date was observed on most of the traits studied because high temperatures, which occurred in late spring during the first experimental year, inhibited pod and seed production and shortened the plants biological life cycle. All the accessions performed better when planting was in November but not later, while earlier planting in the second experimental year, in October, did not result in statistically significantly higher seed production. A planting application from October to November is, therefore, suggested for lupin cultivation in the area. Defining the requirements of L. mutabilis accessions regarding temperature could also be helpful in enhancing seed yield and escaping terminal drought and high temperatures. In planting treatments that took place in the middle to the end of autumn, the prolonged life cycle of indeterminate accessions, named LIB209, LIB214 and LIB223, performed better than the rest of the L. mutabilis accessions tested. LIB209, LIB214 and LIB223 accessions could be further studied as promising breeding material for cultivation under the edaphoclimatic conditions tested.

Supplementary Materials: The following are available online at http://www.mdpi.com/2073-4395/10/12/2020/s1, Table S1. Plant morphological traits of L. mutabilis accessions, under an early or a late planting date treatment, for each one of the two consecutive experimental years (2017-2018) and (2018-2019), Table S2. Pod traits of L. mutabilis accessions, under an early or a late planting date treatment, for each one of the two consecutive experimental years (2017-2018) and (2018-2019), Table S3. Nutrient concentration of L. mutabilis seeds, under an early or a late planting date treatment, of each one of the two consecutive experimental years (2017-2018) and (2018-2019), Table S4. Spearman's rank correlation coefficients among traits studied during the first experimental year (2017-2018), Table S5. Spearman's rank correlation coefficients among traits studied during the second experimental year (2018-2019).

Author Contributions: Conceptualization, P.J.B.; methodology, E.L. and P.J.B.; validation, E.L., G.K.P. and P.J.B.; formal analysis, E.L., G.K.P. and P.J.B.; investigation, E.L.; writing—original draft preparation, E.L.; writing—review and editing, E.L., G.K.P., P.J.B.; visualization, E.L. and P.J.B.; supervision, P.J.B. All authors have read and agreed to the published version of the manuscript.

Funding: This project has received funding from the Bio-based Industries Joint Undertaking under the European Union's Horizon 2020 research and innovation program, grant agreement No 720726 (LIBBIO).

Acknowledgments: The authors would like to thank Instituto Superior de Agronomia (ISA, Lisbon, Portugal) and Vandinter Semo BV, Scheemda, Netherlands for kindly providing Lupinus mutabilis seed material used in this study. We would also like to thank João Neves-Martins for providing LIB224 seeds. We acknowledge Agrogen SA, Greece for providing the L. albus cv. Multitalia and L. angustifolius cv. Polo material included in the study. Also, the authors would like to thank Louis Bolk Instituut for providing the inoculant of Bradyrhizobium lupini (HiStick ${ }^{\circledR}$ ). The authors would like to acknowledge Z. Komi, T. Chatzigeorgiou, K. Argyropoulou and M. Georgiadou, for technical support. PJB would like to thank her undergraduate and graduate students for their support during data collection.

Conflicts of Interest: The authors declare no conflict of interest. All authors read and approved the final manuscript. 


\section{References}

1. Gladstones, J.S. Lupins as crop plants. Field Crop. Abstracts. 1970, 23, 123-148.

2. Mikić, A.; Ćupina, B.; Slobodan, K.; Karagić, Đ. Importance of annual forage legumes in supplying plant proteins. Ratar. Povrt. 2006, 42, 91-103.

3. Kohajdová, Z.; Karovičová, J.; Schmidt, Š. Lupin Composition and Possible Use in Bakery-A Review. Czech J. Food Sci. 2011, 29, 203-211. [CrossRef]

4. Lambers, H.; Clements, J.C.; Nelson, M.N. How a phosphorus-acquisition strategy based on carboxylate exudation powers the success and agronomic potential of Lupines (Lupinus, Fabaceae). Am. J. Bot. 2013, 100, 263-288. [CrossRef] [PubMed]

5. Prusinski, J. White lupin (Lupinus albus L.)-Nutritional and Health Values in Human Nutrition-A Review. Czech J. Food Sci. 2017, 35, 95-105.

6. Uzun, B.; Arslan, C.; Karhan, M.; Toker, C. Fat and fatty acids of white lupin (Lupinus albus L.) in comparison to sesame (Sesamum indicum L.). Food Chem. 2007, 102, 45-49. [CrossRef]

7. Lucas, M.; Stoddard, F.L.; Annicchiarico, P.; Frías, J.; Martinez-Villaluenga, C.; Sussmann, D.; Duranti, M.; Seger, A.; Zander, P.M.; Pueyo, J.J. The future of lupin as a protein crop in Europe. Front. Plant Sci. 2015, 6, 705. [CrossRef]

8. Eastwood, R.J.; Hughes, C.E. Origins of domestication of Lupinus mutabilis in the Andes. In Lupins for Health and Wealth, Proceedings of the 12th International Lupin Conference, Fremantle, Western, Australia, 14-18 September 2008; Palta, J.A., Berger, J.B., Eds.; International Lupin Association: Canterbury, New Zealand, 2008.

9. Eastwood, R.J.; Drummond, C.S.; Schifino-Wittmann, M.T.; Hughes, C.E. Diversity and evolutionary history of Lupins insights from new phylogenies. In Lupins for Health and Wealth, Proceedings of the 12th International Lupin Conference, Fremantle, Western, Australia, 14-18 September 2008; Palta, J.A., Berger, J.B., Eds.; International Lupin Association: Canterbury, New Zealand, 2008.

10. Abraham, E.M.; Ganopoulos, I.; Madesis, P.; Mavromatis, A.; Mylona, P.; Nianiou-Obeidat, I.; Parissi, Z.; Polidoros, A.; Tani, E.; Vlachostergios, D. The Use of Lupin as a Source of Protein in Animal Feeding: Genomic Tools and Breeding Approaches. Int. J. Mol. Sci. 2019, 20, 851. [CrossRef]

11. Kurlovich, B.S. Lupins (Geography, Classification, Genetic Resources and Breeding); OY International North Express: St. Peterburg, Russia; Pellosniemi, Finland, 2002; p. 468.

12. Atchison, G.W.; Nevado, B.; Eastwood, R.J.; Contreras-Ortiz, N.; Reynel, C.; Madriñán, S.; Filatov, D.A.; Hughes, C.E. Lost crops of the Incas: Origins of domestication of the Andean pulse crop tarwi, Lupinus mutabilis. Am. J. Bot. 2016, 103, 1592-1606. [CrossRef]

13. Caligari, P.D.S.; Römer, P.; Rahim, M.A.; Huyghe, C.; Neves-Martins, J.; Sawicka-Sienkiewicz, E.J. The potential of Lupinus mutabilis as a crop. In Linking Research and Marketing Opportunities for Pulses in the 21st Century; Knight, R., Ed.; Springer: Dordrecht, The Netherlands, 2000; Volume 34, pp. 569-573.

14. Jacobsen, S.-E.; Mujica, A. Geographical distribution of the Andean lupin (Lupinus mutabilis Sweet). Plant Genet. Res. Newslett. 2008, 155, 1-8.

15. Gulisano, A.; Alves, S.; Neves Martins, J.; Trindade, L. Genetics and Breeding of Lupinus mutabilis: An Emerging Protein Crop. Front. Plant Sci. 2019, 10, 1385. [CrossRef] [PubMed]

16. Neves Martins, J.M.; Talhinhas, P.; de Sousa, R.B. Yield and seed chemical composition of Lupinus mutabilis in Portugal. Rev. Ciências Agrárias 2016, 39, 518-525. [CrossRef]

17. Staples, K.D.; Hamama, A.A.; Knight-Mason, R.; Bhardwaj, H.L. Alkaloids in White Lupin and Their Effects on Symbiotic N Fixation. J. Agr Sci. 2017, 9, 13-21. [CrossRef]

18. Römer, P.; Jahn-Deesbach, W. Eight years of experiences in breeding Lupinus mutabilis under middle European conditions. In Agrimed Research Programme-Lupinus Mutabilis: Its Adaptation And Production Under European Pedoclimatic Conditions; Commission of the European Communities: Brussels, Belgium, 1992; pp. 79-85, EUR 14102 EN: Luxembourg.

19. Galek, R.; Sawicka-Sienkiewicz, E.; Zalewski, D.; Stawiński, S.; Spychala, K. Searching for Low Alkaloid Forms in the Andean Lupin (Lupinus mutabilis) Collection. Czech J. Genet. Plant Breed. 2017, 53, 55-62. [CrossRef]

20. Von Baer, E. Domestication of Andean Lupin (L. mutabilis). In Lupin Crops-An Opportunity for Today, a Promise for the Future, Proceedings of the 13th International Lupin Conference, Poznan, Poland, 6-10 June 2011; Naganowska, B., Kachlicki, P., Wolko, B., Eds.; International Lupin Association: Canterbury, New Zealand, 2011. 
21. Adomas, B.; Galek, R.; Gas-Seremeka, M.; Helios, W.; Hurej, M.; Kotecki, A.; Kozak, M.; Malarz, W.; Okorski, A.; Piotrowicz-Cieślak, A.I.; et al. Adaptation of the Andean Lupin (Lupinus mutabilis Sweet) to Natural Conditions of South-Western Poland; Kotecki, A., Ed.; Monography CXCV; Wroclaw University of Environmental and Life Sciences: Wrocław, Poland, 2015; p. 121.

22. Bebeli, P.J.; Lazaridi, E.; Chatzigeorgiou, T.; Suso, M.-J.; Hein, W.; Alexopoulos, A.A.; Canha, G.; van Haren, R.J.; Jóhannsson, M.H.; Mateos, C.; et al. State and Progress of Andean Lupin Cultivation in Europe: A Review. Agronomy 2020, 10, 1038. [CrossRef]

23. Sawicka-Sienkiewicz, E.; Galek, R.; Zalewski, D.; Augiewicz, J. Porównanie mieszańców międzygatunkowych Lupinus albus (sensu lato) x Lupinus mutabilis pod względem wybranych cech ilościowych. Biul. Inst. Hod. Aklim. Roślin 2006, 240-241, 253-259.

24. Clements, J.; Galek, R.; Kozak, B.; Michalczyk, D.J.; Piotrowicz-Cieślak, A.I.; Sawicka-Sienkiewicz, E.; Stawiński, S.; Zalewski, D. Diversity of Selected Lupinus angustifolius L. Genotypes at the Phenotypic and DNA Level with Respect to Microscopic Seed Coat Structure and Thickness. PLoS ONE 2014, 9, e102874. [CrossRef]

25. Galek, R.; Kozak, B.; Biela, A.; Zalewski, D.; Sawicka-Sienkiewicz, E.; Spychała, K.; Stawiński, S. Seed Coat Thickness Differentiation and Genetic polymorphism for Lupinus mutabilis Sweet breeding. Turk. J. Field Crop. 2016, 21, 305-312.

26. Hardy, A.; Huyghe, C.; Rahirne, M.A.; Roemer, P.; Neves-Martins, J.M.; Sawieka-Sienkiewiez, E.; Caligarie, P.D.S. Effects of genotype and environment on architecture and flowering time of indeterminate Andean lupins (Lupinus mutabilis Sweet). Aust. J. Agric. Res. 1998, 49, 1241-1251. [CrossRef]

27. Horn, P.E.; Hill, G.D.; Porter, N.G. Yield and Nutrient Composition of Seventeen Lupinus Mutabilis Lines; Proceedings Agronomy Society of New Zealand 8; Lincoln College: Lincoln, UK, 1978.

28. Römer, P. A determinated mutant of L. mutabilis as a possible source of early maturity. In Advances in Lupin Research, Proceedings of the 7th International Lupin conference, Evora, Portugal, 18-23 April 1993; ISA Press: Lisbon, Portugal, 1994; pp. 18-23.

29. Sawicka-Sienkiewicz, E. The induced mutations in Andean lupine (Lupinus mutabilis Sweet). Monogr. Rozpr. 1993, 3, 1-112.

30. Sawicka-Sienkiewicz, E.J.; Augiewicz, J. Genetic studies of Andean lupin (Lupinus mutabilis Sweet). In Wild and Cultivated Lupins from the Tropics to the Poles, Proceedings of the 10th International Lupin Conference, Laugarvatn, Iceland, 19-24 June 2002; van Santen, E., Hill, H.D., Eds.; International Lupin Association: Canterbury, New Zealand, 2002; p. 136.

31. Pszczółkowska, A.; Okorski, A.; Kotecki, A.; Gas, M.; Kullik, T.; Reczek, A. Incidence of seed-borne fungi on Lupinus mutabilis depending on a plant morphotype, sowing date and plant density. J. Elem. 2016, 21, 501-512. [CrossRef]

32. Gas, M. Wpływ Wybranych Czynników Agrotechnicznych na Rozwój i Plonowanie Łubinu Andyjskiego (Lupinus mutabilis Sweet) [The Influence of Selected Agronomic Factors on the Development and Yielding of Andean Lupine (Lupinus Rnutabilis Sweet)]. Ph.D. Thesis, Wroclaw University of Environmental and Life Sciences, Wroclaw, Poland, 2014.

33. López-Bellido, L.; Fuentes, M. Growth, yield and yield components of lupin cultivars. Agron. J. 1990, 82, 1050-1056. [CrossRef]

34. Vaz Patto, M.C.; Talhinhas, P.; Martins, J.N. Studies on genetic variability and architecture of Lupinus mutabilis Sweet populations. In Towards the 21st Century, Proceedings of the 8th International Lupin Conference, Asilomar, CA, USA, 11-16 May 1996; Hill, G., Ed.; International Lupin Association: Canterbury, New Zealand, 1996; pp. 378-383.

35. Guilengue, N.; Alves, S.; Talhinhas, P.; Neves-Martins, J. Genetic and genomic diversity in a tarwi (Lupinus mutabilis Sweet) germplasm collection and adaptability to Mediterranean climate conditions. Agronomy 2020, 10, 21. [CrossRef]

36. Yassoglou, N.; Tsadilas, C.; Kosmas, C. The Soils of Greece; Hartemink, A.E., Ed.; Springer International Publishing AG: Cham, Switzerland, 2017.

37. Statgraphics Centurion XVII 2016, Version 17.2.0.0; StatPoint, Inc.: Herndon, DC, USA, 2016.

38. StatSoft 2007, Statistica Package Release 8; StatSoft, Inc.: Tulsa, OK, USA, 2007.

39. SAS Institute Inc. 2008, JMP/Sales Department; SAS Institute Inc.: Cary, CA, USA, 2008. 
40. Microsoft Corporation. 2019. Available online: https://office.microsoft.com/excel (accessed on 21 October 2020).

41. Adhikari, K.; Buirchell, B.; Sweetingham, M. Effect of vernalization on various Lupin species at different time intervals. In Lupins for Health and Wealth, Proceedings of the 12th International Lupin Conference, Fremantle, Western Australia, 14-18 September 2008; Palta, J.A., Berger, J.B., Eds.; International Lupin Association: Canterbury, New Zealand, 2008.

42. Walker, J.; Hertel, K.; Parker, P.; Edwards, Y. Lupin Growth and Development. In ProCrop. Ser.; Edwards, J., Walker, J., McIntosh, G., Eds.; State of New South Wales through NSW Department of Industry and Investment (Industry \& Investment NSW): New South Wales, Australia, 2011; p. 81.

43. White, P.; French, B.; McLarty, A. Grains Research and Development Corporation. Producing Lupins, Bulletin 4720, 2nd ed.; Department of Agriculture and Food: Perth, Australia, 2008; pp. 31-32.

44. Lizarazo, C.; Stoddard, F.; Mäkelä, P.; Santanen, A. Genetic variability in the physiological responses of Andean lupin to drought stress. Suom. Maatal. Seuran Tied. 2010, 31, 1-5. [CrossRef]

45. Adhikari, K.N.; Buirchell, B.J.; Sweetingham, M.W. Length of vernalization period affects flowering time in three lupin species. Plant Breed. 2012, 131, 631-636. [CrossRef]

46. Sita, K.; Sehgal, A.; Hanumantha Rao, B.; Nair, R.M.; Vara Prasad, P.V.; Kumar, S.; Gaur, P.M.; Farooq, M.; Siddique, K.H.M.; Varshney, R.K.; et al. Food Legumes and Rising Temperatures: Effects, Adaptive Functional Mechanisms Specific to Reproductive Growth Stage and Strategies to Improve Heat Tolerance. Front. Plant Sci. 2017, 8, 1658. [CrossRef]

47. López-Bellido, L.; Fuentes, M.; Lhamby, J.C.B.; Castillo, J.E. Growth and yield of white lupin (Lupinus albus) under Mediterranean conditions: Effect of sowing date. Field Crop. Res. 1994, 36, 87-94. [CrossRef]

48. Keeve, R.; Loubser, H.L.; Krüger, G.H.J. Effects of Temperature and Photoperiod on Days to Flowering, Yield and Yield Components of Lupinus albus (L.) under Field Conditions. J. Agron. Crop. Sci. 2000, 184, 187-196. [CrossRef]

49. Christiansen, J.L.; Jørnsgård, B. Influence of daylength and temperature on number of main stem leaves and time to flowering in lupin. Ann. Appl. Biol. 2002, 140, 29-35. [CrossRef]

50. Zalewski, D.; Galek, R.; Kozak, B.; Sawicka-Sienkiewicz, E. Pheno-Morphological and Agronomic diversity in a collection of wild and domesticated species of the genus Lupinus. Turk. J. Field Crop. 2015, 20, 43-48.

51. Talhinhas, P.; Vaz Patto, M.C.; Martins, J.N.; Römer, P.; Huyghe, C.; Rahim, M.; Caligari, P. Evaluation of Lupinus mutabilis Sweet cultivars under Mediterranean conditions. In Towards the 21st century, Proceedings of the 8th International Lupin Conference, Asilomar, CA, USA, 11-16 May 1996; Hill, G., Ed.; International Lupin Association: Canterbury, New Zealand, 1996; pp. 87-93.

52. Hardy, A.; Huyghe, C.; Papineau, J. Dry matter accumulation and partitioning, and seed yield in indeterminate Andean lupin (Lupinus mutabilis Sweet). Aust. J. Agric. Res. 1997, 48, 91-102. [CrossRef]

53. Falconi, C.E. Lupinus mutabilis in Ecuador with special emphasis on anthracnose resistance. Ph.D. Thesis, Wageningen University, Wageningen, The Netherlands, 2012.

54. Tang, C.; Robson, A.D.; Longnecker, N.E.; Buirchell, B.J. The Growth of Lupinus Species on Alkaline Soils. Aust. J. Agric. Res. 1995, 46, 255-268. [CrossRef]

55. Tang, C.; Adams, H.; Longnecker, N.E.; Robson, A.D. A method to identify lupin species tolerant of alkaline soils. Aust. J. Exp. Agric. 1996, 36, 595-601. [CrossRef]

56. Kerley, S.J.; Huyghe, C. Comparison of acid and alkaline soil and liquid culture growth systems for studies of shoot and root characteristics of white lupin (Lupinus albus L.) genotypes. Plant Soil 2001, 236, 275-286. [CrossRef]

57. Podleśny, J. Przydatność siewu punktowego w uprawie wybranych gatunków roślin strączkowych. Inżynieria Rol. 2006, 13, 385-392.

58. Agrimed Research Programme. Lupinus mutabilis: It's adaptation and production under European pedoclimatic conditions. In Proceedings of a Workshop, Cascais, Portugal, 26-27 April 1992; Commission of the European Communities, Ed.; Office for Official Publications of the European Communities: Brussels, Belgium, 1992.

59. Huyghe, C. Genetics and genetic modifications of plant architecture in grain legumes: A review. Agronomie 1998, 18, 383-411. [CrossRef]

60. Romer, P. New attempts to select early maturing Lupinus mutabilis for middle Europe. In Proceedings of the 2nd European Conference on Grain Legumes, Copenhagen, Denmark, 9-13 July 1995. 
61. Iannucci, A.; Terribile, M.R.; Martiniello, P. Effects of temperature and photoperiod on flowering time of forage legumes in a Mediterranean environment. Field Crop. Res. 2008, 106, 156-162. [CrossRef]

62. Roberts, E.H.; Summerfield, R.J. Measurement and prediction of flowering in annual crops. In Manipulation of Flowering; Atherton, J.G., Ed.; Ž. Butterworth: London, UK, 1987; pp. 17-50.

63. Sandaña, P.A.; Harcha, C.I.; Calderini, D.F. Sensitivity of yield and grain nitrogen concentration of wheat, lupin and pea to source reduction during grain filling. A comparative survey under high yielding conditions. Field Crop. Res. 2009, 114, 233-243. [CrossRef]

64. Karaguzel, O.; Baktir, I.; Cakmakci, S.; Ortacesme, V.; Aydinoglu, B.; Atika, M. Responses of native Lupinus varius (L.) to culture conditions: Effects of photoperiod and sowing time on growth and flowering characteristics. Sci. Hortic. 2005, 103, 339-349. [CrossRef]

65. Gross, R. Fitomejoramiento. In El cultivo y la Utilizacion del Tarwi Lupinus Mutabilis Sweet; Organización de las Naciones Unidas para la Agricultura y la Alimentación, Ed.; Estudio FAO: Producción y proteccion vegetal; FAO: Roma, Italy, 1982; Volume 36, pp. 235-236.

66. Keatinge, J.D.H.; Qi, A.; Wheeler, T.R.; Ellis, R.H.; Summerfield, R.J. Effects of temperature and photoperiod on phenology as a guide to the selection of annual legume cover and green manure crops for hillside farming systems. Field Crop. Res. 1998, 57, 139-152. [CrossRef]

67. Krasulina, M.I. Vernalization of lupin. Sel. Semenovod 1937, 4, 51-54.

68. Silvester-Bradley, R. The effect of sowing date in the development of Lupinus albus in the United Kingdom and its optimum plant density. In Agricultural and Nutritional Aspects of Lupines, Proceedings of the 1st International Lupine Workshop, Lima-Cuzco, Peru, 12-21 April 1980; Gross, R., Bunting, E.S., Eds.; German Agency for Technical Cooperation (GTZ): Eschborn, Germany, 1980.

69. Myers, L.F.; Christian, K.R.; Kirchner, R.J. Flowering responses of 48 lines of oilseed rapes (Brassica spp.) to vernalisation and daylength. Aust. J. Agric. Res. 1982, 33, 927-936. [CrossRef]

70. Palta, J.A.; Ludwig, C. Elevated $\mathrm{CO}_{2}$ during pod filling increased seed yield but not harvest index in indeterminate narrow-leafed lupin. Aust. J. Agric. Res. 2000, 51, 279-286. [CrossRef]

71. Palta, J.A.; Turner, N.C.; French, R.J.; Buirchell, B.J. Physiological responses of lupin genotypes to terminal drought in a Mediterranean-type environment. Ann. Appl. Biol. 2007, 150, 269-279. [CrossRef]

72. Sehgal, A.; Sita, K.; Siddique, K.H.M.; Kumar, R.; Bhogireddy, S.; Varshney, R.K.; Hanumantha Rao, B.; Nair, R.M.; Prasad, P.V.V.; Nayyar, H. Drought or/and Heat-Stress Effects on Seed Filling in Food Crops: Impacts on Functional Biochemistry, Seed Yields, and Nutritional Quality. Front. Plant Sci. 2018, 9, 1705. [CrossRef]

73. Duthion, C.; Pigeaire, A. Seed lengths corresponding to the final stage in seed abortion of three grain legumes. Crop. Sci. 1991, 31, 1579-1583. [CrossRef]

74. Palta, J.A.; Turner, N.C.; French, R.J. Drought tolerance of lupin genotypes in Western Australia. In 2000 Lupin Update; O'Neill, B., Ed.; Western Australia Department of Agriculture: Perth, Australia, 2000; pp. $43-45$.

75. Gonzalez-Dugo, V.; Durand, J.-L.; Gastal, F. Water deficit and nitrogen nutrition of crops. A review. Agron. Sustain. Dev. 2010, 30, 529-544. [CrossRef]

76. Blum, A.; Sinmena, B.; Mayer, J.; Golan, G.; Shpiler, L. Stem reserve mobilisation supports wheat grain filling under heat stress. Aust. J. Plant Physiol. 1994, 21, 771-781. [CrossRef]

77. Chaves, M.M.; Maroco, J.P.; Pereira, J.S. Understanding plant responses to drought-From genes to the whole plant. Funct. Plant Biol. 2003, 30, 239-264. [CrossRef]

78. Matimati, I.; Verboom, G.; Cramer, M. Nitrogen regulation of transpiration controls mass-flow acquisition of nutrients. J. Exp. Bot. 2013, 65, 159-168. [CrossRef]

79. Farooq, M.; Wahid, A.; Kobayashi, N.; Fujita, D.; Basra, S.M.A. Plant drought stress: Effects, mechanisms and management. Agron. Sustain. Dev. 2009, 29, 185-212. [CrossRef]

80. Stark, J.M.; Firestone, M.K. Mechanisms for soil moisture effects on activity of nitrifying bacteria. Appl. Environ. Microbiol. 1995, 61, 218-221. [CrossRef] [PubMed]

81. Leghari, S.J.; Wahocho, A.; Laghari, G.M.; Laghari, A.H.; Bhabhan, G.M.; Talpur, K.H.; Bhutto, T.A.; Wahocho, S.A.; Lashari, A.A. Role of Nitrogen for plant growth and development: A Review. ADN. Environ. Biol. 2016, 10, 209-218.

82. Carvajal-Larenas, F.E.; Linnemann, A.R.; Nout, M.J.R.; Koziol, M.; van Boekel, M.A.J.S. Lupinus mutabilis: Composition, Uses, Toxicology, and Debittering. Crit. Rev. Food Sci. Nutr. 2016, 56, 1454-1487. [CrossRef] [PubMed] 
83. Leytem, A.B.; Mikkelsen, R.L. The nature of phosphorus in calcareous soils. Better Crop. 2005, 89, 11-13.

Publisher's Note: MDPI stays neutral with regard to jurisdictional claims in published maps and institutional affiliations.

(C) 2020 by the authors. Licensee MDPI, Basel, Switzerland. This article is an open access article distributed under the terms and conditions of the Creative Commons Attribution (CC BY) license (http://creativecommons.org/licenses/by/4.0/). 